\title{
REVIEW ON THE HYDROGEOCHEMICAL EVALUATION OF LUSHNJA AQUIFER GROUNDWATERS
}

\author{
Iris Bakiri $^{1^{*}}$, Arben Pambuku${ }^{2}$, Eduard Andoni ${ }^{3}$ \\ ${ }^{1 *}$ Institute of Applied Nuclear Physics, University of Tirana, Albania; \\ ${ }^{2}$ Department of Hydrogeology, Albanian Geological Survey, Tirana, Albania; \\ ${ }^{3}$ University of Tirana, Faculty of Natural Sciences, Department of Chemistry, Tirana, Albania; \\ "Corresponding Author Iris Bakiri, e-mail: iris.bakiri@unitir.edu.al;
}

Received April 2021; Accepted May 2021; Published June 2021;

DOI: https://doi.org/10.31407/ijees11.334

\begin{abstract}
The groundwater of the quaternary aquifer of Lushnja is the primary source of the public drinking water supply for the population and it is often use even for irrigation in the Lushnja district. Groundwater plays an important role in the supply of drinking water, functioning of ecosystems and the well-being of people. The study area is situated on the Peri-Adriatic Depression and is underlain by gravel deposits of Quaternary age. The Lushnja aquifer is characterized by alluvial deposits of Holocene lithologically represented by alevrites, sand, and gravel. It spreads almost all over the plain part of the Lushnja district from the Shkumbin River to the north, up to the Seman River to the south, and in the Fier-Shegan sector is connected to Berat's plain. The climate of the Lushnja area is characterized by Mediterranean subtropical sub area climate marked by short warm winters and long hot dry summer seasons. A total of 31 samples were collected in spring 2011. There were measured the concentration of major cations $\{(\mathrm{Na}(+), \mathrm{Ca}(2+), \mathrm{Mg}(2+)$ and $\mathrm{K}(+)\}$, major anions $\{\mathrm{Cl}(-), \mathrm{SO} 4(2-)$ and $\mathrm{HCO} 3(-)\}$, electrical conductivity and total dissolved solids. The results of the hydrochemical analysis reveal that the order of cations dominance was $\mathrm{Mg}^{2+}>\mathrm{Ca}^{2+}>\left(\mathrm{Na}^{+}+\mathrm{K}\right)$ for the cations and $\left(\mathrm{HCO}_{3}{ }^{-}+\mathrm{CO}_{3}{ }^{2-}\right)>\mathrm{Cl}^{-}$for the anions. Further analysis shows that the main type of water of the groundwaters present in the Lushnja is $\left(\mathrm{Mg}^{2+}+\mathrm{Ca}^{2+}\right)-\mathrm{HCO}_{3}$.
\end{abstract}

Keywords: groundwater; hydrochemistry; chemical classification; water type; aquifer 